\title{
Clinico epidemiological profile of HIV - TB coinfection among PLHIV in coastal south India
}

\author{
Unnikrishnan Bhaskaran \\ From International Symposium HIV and Emerging Infectious Diseases 2014 \\ Marseille, France. 21-23 May 2013
}

\section{Background}

Tuberculosis is the most common opportunistic infection diagnosed in HIV positive patients in India. HIV and Tuberculosis co-infection is a major public health problem as well as a leading cause of death in developing countries.

\section{Aims}

To study the trends and clinico epidemiological profile of HIV and tuberculosis co-infection from January 2008 to December 2011.

\section{Method}

A hospital based retrospective study was conducted on all subjects having HIV and Tuberculosis co-infection from January 2008 to December 2011. Data was collected using semi-structured proforma from Integrated Counselling and Testing Center (ICTC) records. All analysis was done using SPSS version 11.5. Statistical test Chi-square was done.

\section{Results}

In 2011, 17.3\% HIV positive cases were co-infected with tuberculosis in comparison to $6.5 \%$ in $2008,14.9 \%$ in 2009 and $8.5 \%$ in 2010. HIV and Tuberculosis co-infection was more prevalent in males $(69.3 \%)$ than in females (30.7\%) and $90.9 \%$ of the study subjects were married. Most of the co-infected cases (89.8\%) were on anti-tubercular treatment.

\section{Conclusion}

HIV and Tuberculosis co-infection is under-diagnosed and under-treated. Thus there is a need to integrate Tuberculosis and HIV prevention programmes to face the threat of HIV associated tuberculosis.

Kasturba Medical College, Manipal University, Mangalore, India
Published: 23 May 2014

doi:10.1186/1471-2334-14-S2-P32

Cite this article as: Bhaskaran: Clinico epidemiological profile of HIV - TB coinfection among PLHIV in coastal south India. BMC Infectious Diseases 2014 14(Suppl 2):P32.
Submit your next manuscript to BioMed Central and take full advantage of:

- Convenient online submission

- Thorough peer review

- No space constraints or color figure charges

- Immediate publication on acceptance

- Inclusion in PubMed, CAS, Scopus and Google Scholar

- Research which is freely available for redistribution
() Biomed Central 